\title{
Rates of change and chronological problems during the late-glacial period*
}

\author{
André F Lotter ${ }^{1}$, Brigitta Ammann ${ }^{2}$, and Michael Sturm ${ }^{1}$ \\ ${ }^{1}$ EAWAG-ETH, Umweltphysik, CH-8600 Dübendorf, Switzerland \\ ${ }^{2}$ Universität Bern, Syst.-Geobot. Institut, Altenbergrain 21, CH-3013 Bern, Switzerland
}

Received February 6, 1991/Accepted August 12, 1991

\begin{abstract}
Results of high-resolution AMS ${ }^{14} \mathrm{C}$ dating of terrestrial plant macrofossils from late-glacial and early-Holocene lake deposits in Switzerland show three periods with constant radiocarbon ages. These plateaux of constant age occur at 12700,10000 , and 9500 y BP. A comparison of this radiocarbon chronology with a varve chronology documents discrepancies between the sidereal and the radiocarbon time-scale for the late-glacial period. The age-plateaux and the time-scale discrepancies have a significant impact on the estimation of rates of change during this period: estimates of rates of change can be very misleading if calculated on the basis of radiocarbon ages. This is illustrated by an example of estimated rates of late-glacial and early Holocene palynological change in Switzerland.
\end{abstract}

\section{Introduction}

The deglaciation and the early post-glacial period following the last ice-age are characterized by several climatic fluctuations which are well-reflected in the proxy-data record of lacustrine sediments. The speed at which these oscillations took place is a critical factor in understanding the mechanisms behind rapid changes in climate and, closely related to this, the response of ecosystems to rapid climatic change.

Rates of change are estimates of the amount of change per unit time. If estimated from proxy-data they can, in theory, help to infer the rate and amount of change in the past. The most important factor, however, for a reliable estimation of any rate of change is the time-scale. In the case of proxy-data from lacustrine deposits this time-scale is provided by an age-depth relationship that can be established on the basis of var-

\footnotetext{
* Contribution to Clima Locamo - Past and Present Climate Dynamics; Conference September 1990, Swiss Academy of Sciences - National Climate Program
}

Offprint requests to: AF Lotter ious dating methods: several radiocarbon dates throughout a sediment core commonly provide a chronology for changes observed in the proxy record. However, the basic assumptions of any rate-of-change estimation from proxy-data are:

1. The palaeoecological variable being used (e.g. pollen) is an ecologically important component in the system of interest, or is linearly related to it.

2. The mathematical measure used to quantify differences in composition among samples adequately models the differences.

3. The proxy-data are comparable from one sample to another (same taxonomy, count size, preparation procedure, analyst, etc.).

4. The time standardization unit is reliable and is in the same units throughout. Moreover, it should cover the identical sidereal period throughout. In fact, $100{ }^{14} \mathrm{C}$ years may not equal 100 years everywhere in the lateGlacial or Holocene.

Since the early days of pollen analysis (e.g. Oberdorfer 1937), two periods of rapid change in flora and vegetation have been well-known from pollen studies at many sites in Central Europe: the late-glacial reforestation and the change from coniferous to deciduous forests in the early Holocene. The ${ }^{14} \mathrm{C}$-ages usually now assigned to these periods are 13000 to $12500 \mathrm{y} \mathrm{BP}$ and 10000 y BP, respectively. These two periods of considerable vegetational change are not only recorded in a wide geographical area of the European lowlands but also at higher altitudes, e.g. on the Simplon Pass (2000 m a.s.l., Küttel 1979; Welten 1982; Lang and Tobolski 1985). In addition, biostratigraphies other than pollen similarly show major shifts in the older of these two periods, e.g. Coleoptera and Trichoptera (Elias and Wilkinson 1983, 1985), chironomids (Hofmann 1983, 1985a), and Cladocera (Hofmann 1985b). These faunal changes represent shifts from boreomontane, subarctic, cold-stenotherm to temperate faunas.

The aim of the present contribution is to emphasise the overall importance of an accurate chronology for a sound reconstruction of rates of change. The example chosen concerns palynology and therefore, by infer- 
ence, the past vegetation. However, the problems discussed here relate to the reconstruction of rates of change in every aspect of Quaternary science.

\section{The pollen data}

Late-glacial pollen stratigraphies are available from Rotsee ( $420 \mathrm{~m}$ a.s.1.) and Soppensee (590 $\mathrm{m}$ a.s.1.). Both lakes are located on the Central Swiss Plateau close to the border of the Alps (Fig. 1): Rotsee lies at the northern periphery of Lucerne and Soppensee is located $18 \mathrm{~km}$ to the NW (Lotter 1988, 1990). Because of the short geographical distance between the two sites, their pollen records are very comparable.

Both pollen records were subdivided into the Firbas $(1949,1954)$ pollen zones (Fig. 2,3$)$, considered here as strict biozones (i.e. regional pollen assemblage zones). They must not be confused with the chronozones (Mangerud et al. 1974) that have the same names (see Ammann \& Lotter 1989). These regional pollen zones are characterized (see e.g. Zoller 1987; Lotter 1988; Ammann 1989a) in the following way.

Zone Ia (Oldest Dryas) is characterized by high values of non-arboreal pollen (NAP), mainly heliophilous taxa (e.g. Artemisia, Helianthemum, Caryophyllaceae) and grasses (Poaceae). These assemblages are commonly interpreted as a tree-less steppe-tundra on open soils, consisting of a mosaic of arctic and alpine herbs. Towards the top of this zone an increase in dwarf shrubs (Betula nana, Salix spp.) occurs, indicating the onset of a denser vegetation cover.

Zone $\mathrm{Ib} / \mathrm{c}$ (Bølling) is marked in its first part by a shrub phase consisting of Juniperus and Hippophaë. Its second part includes the expansion of tree birch (Betula) and the decrease of the NAP. This represents the

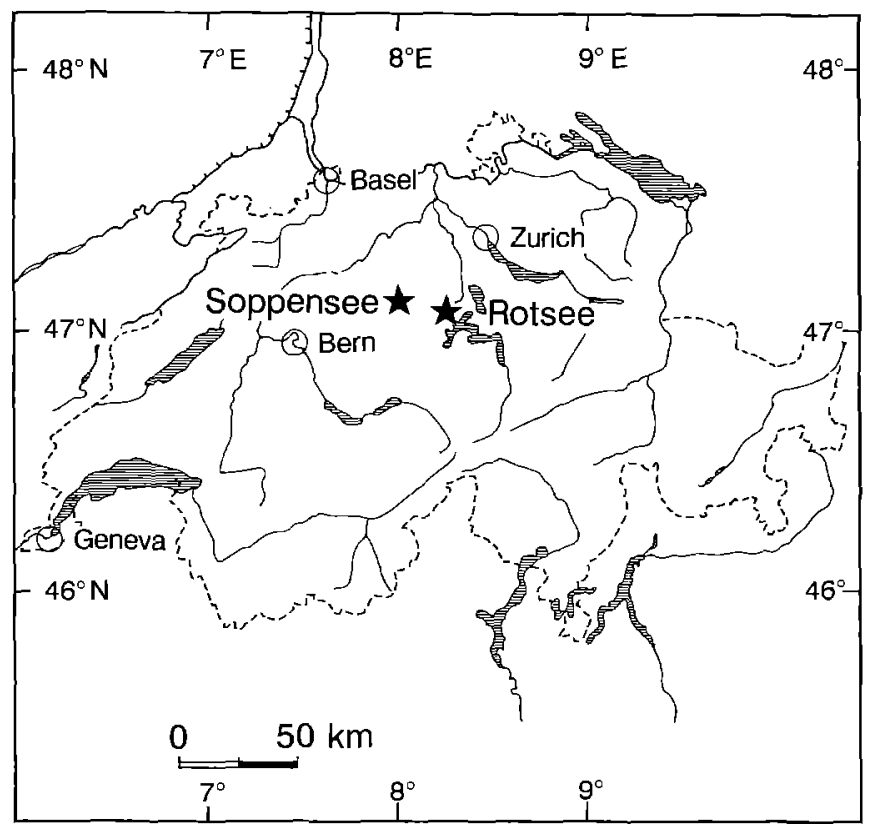

Fig. 1. Map of Switzerland with location of the two investigated sites important event of reforestation. The vegetation was characterized by birch forests with tall herbs. The lithological record usually reflects this denser vegetation cover by a change from minerogenic to organic or carbonate sediments. At some sites a regressive phase in the vegetation development marked by an increase in heliophilous NAP and a depression in Betula can be observed towards the end of this zone (Fig. 3).

The onset of zone II (Allerød) is represented by in creasing Pinus (pine) values. The entire zone is dominated by pine pollen with decreasing birch percentages. The vegetation of this zone until the early Holocene is characterized by pine forests with some birch.

Zone III (Younger Dryas) represents a second regressive phase. It is characterized by an increase of heliophilous taxa (mainly Artemisia and Juniperus). The vegetation of this zone consisted of open pine and birch forest.

The transition from zone III to IV (Preboreal), marked by decreasing NAP values, is also the transition from the late-glacial to the Holocene. The onset of zone $\mathrm{V}$ (Boreal) is marked by decreasing pine values and increasing values of mesic trees (Corylus, Ulmus, Quercus, Tilia) and thus the development of the Holocene mixed deciduous forest.

\section{The chronologies}

At Rotsee an extensive AMS ${ }^{14} \mathrm{C}$-dating series on over 60 plant-macrofossil samples has been carried out in connection with pollen and stable-isotope analyses (Ammann and Lotter 1989; Lotter and Zbinden 1989). By dating exclusively plant remains of terrestrial origin (mainly fruits and catkin scales of Betula), hardwater dating errors have been avoided. Following Stuiver and Polach (1977), all dates are expressed as conventional radiocarbon years BP (before 1950).

The high-resolution ${ }^{14} \mathrm{C}$ chronology from Rotsee (Fig. 2) displays three distinct phases of nearly constant radiocarbon age. These age-plateaux are situated at 12700,10000 , and $9500 \mathrm{y} \mathrm{BP}$. The occurrence of these plateaux is not only restricted to Rotsee but can also be found in other lacustrine records, such as Lobsigensee (Andrée et al. 1986; Ammann and Lotter 1989; Zbinden et al. 1989). Moreover, the two younger plateaux have also been detected in the dendrochronological record (Becker and Kromer 1986, 1990). These plateau-phases coincide with highly dynamic phases of environmental change (Ammann 1989b): the $12700 \mathrm{BP}$ plateau includes the first major change in oxygen isotopes (Lotter 1988; Lotter and Zbinden 1989) as well as the reforestation after the climatic warming of Bølling. The plateau at $10000 \mathrm{BP}$ includes the oxygen-isotope change at the end of the Younger Dryas as well as the transition from Younger Dryas to Preboreal, i.e. the transition from the late-glacial period to the Holocene. The $9500 \mathrm{BP}$ plateau, which is only present as its lower part in the Rotsee dating series, occurs during the ecologically important change from coniferous to deciduous forest. 

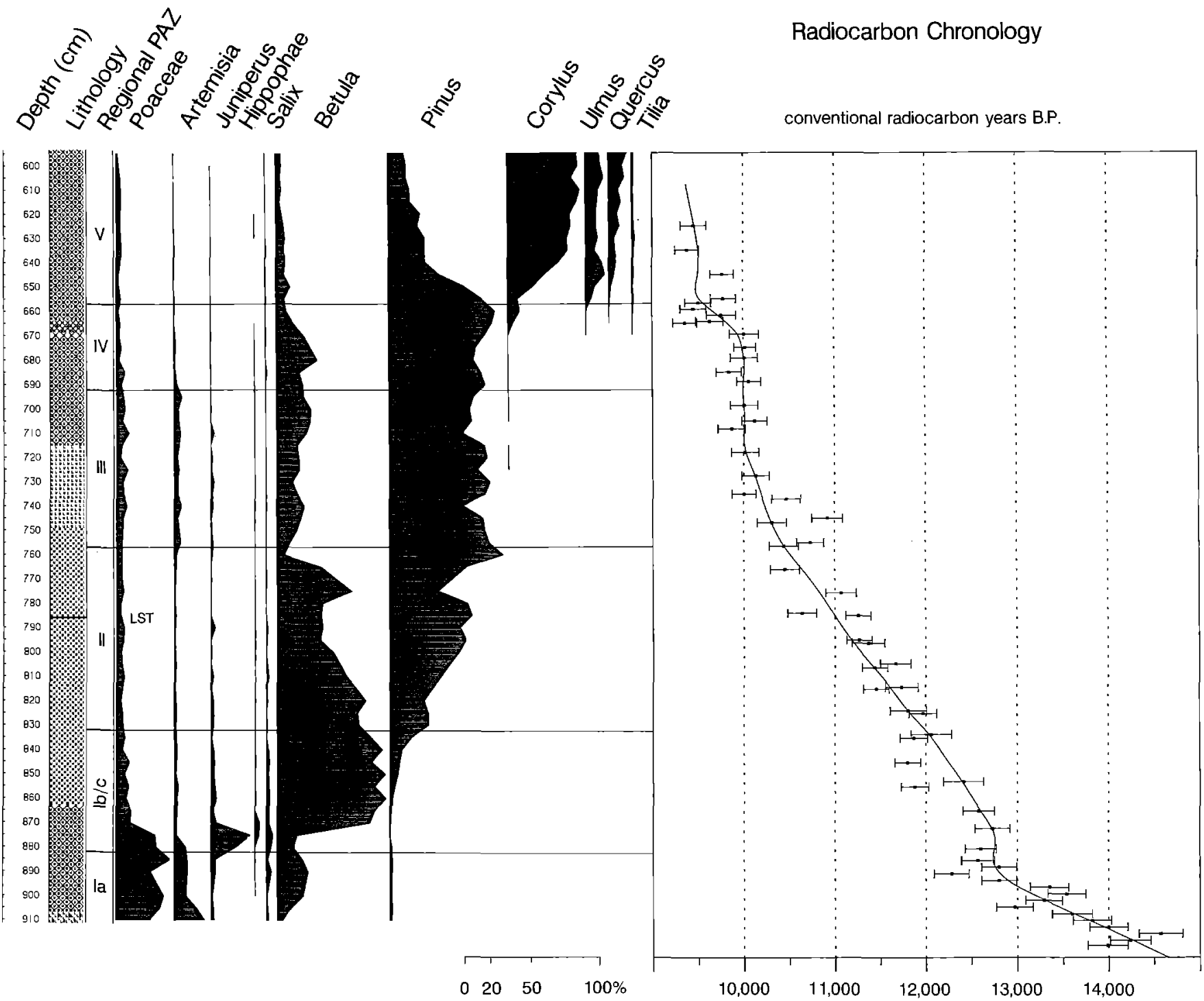

Fig. 2. Rotsee ( $420 \mathrm{~m}$ a.s.l.), core RL-300: simplified pollen diagram and radiocarbon chronology for the late-glacial period and the early Holocene. The lithology is modified after Troels-Smith (1955) and the pollen zones refer to Firbas $(1949,1954) . L S T$ :

Laacher See Tephra. The AMS radiocarbon dates on terrestrial plant macrofossils include $\pm 1 \sigma$ and originate from cores RL-300 and RL-305 (for details see Lotter 1988; Ammann and Lotter 1989)

Events during these plateaux are often lumped together because of coarse sampling resolution. The problems connected with these phases of constant radiocarbon age and their consequences have been discussed elsewhere (Ammann 1989b; Ammann and Lotter 1989; Lotter and Zbinden 1989). The most important consequences are:

1. An accurate correlation and comparison of stratigraphies between sites is difficult for these plateau phases.

2. The dates of 12700,10000 , and 9500 y BP frequently found for marked biotic changes at many sites might group together events at different times, and we then erroneously regard them as synchronous.

3. It becomes difficult, if not impossible, to calculate meaningful accumulation rates or rates of change on the basis of radiocarbon dates during these plateau periods.
The sediment of Soppensee exhibits laminations that are of annual nature, i.e. biogenic varves (Lotter 1989; 1991a). These varves start soon after the birch expansion of Bølling $(\mathrm{Ib} / \mathrm{c})$ and gradually cease in mid-Atlantic. Triplicate varve counts performed on sediment thin-sections of core SO86-14 yielded a total number of approximately 6000 years. Although this preliminary Soppensee varve chronology is still floating, it represents an excellent tool for radiocarbon-independent time estimates. We therefore can overcome some of the problems associated with the plateaux of constant ${ }^{14} \mathrm{C}$ age.

Moreover, a first estimate of the absolute time span for the late-glacial regional pollen zones is now possible. A preliminary comparison between the duration of these zones in radiocarbon and in sidereal years shows major discrepancies (Fig. 4): the significant differences occur during the Allerød biozone (II: ca. 600 varves 

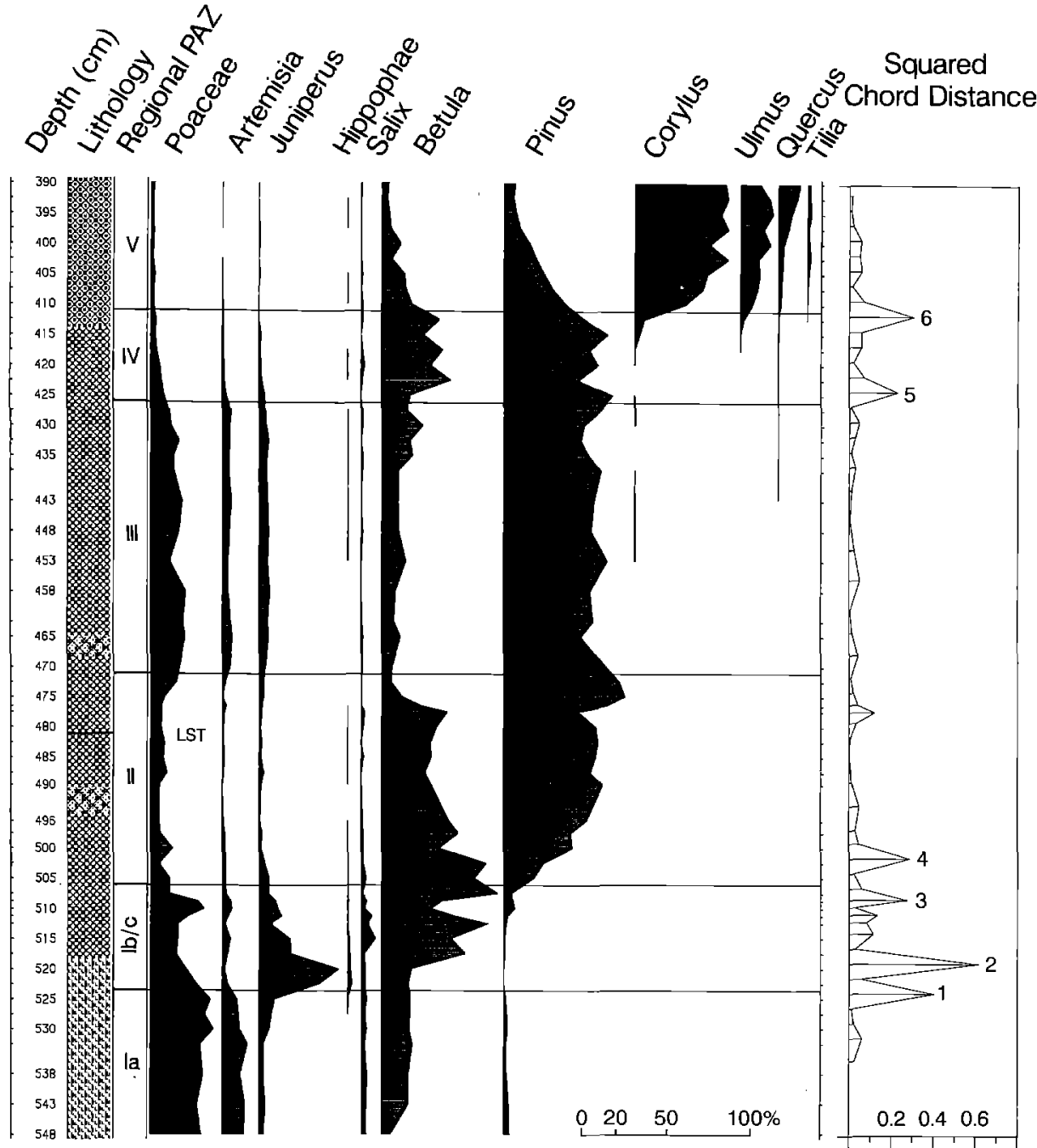

Fig. 3. Soppensee ( $600 \mathrm{~m}$ a.s.1.), core SO86-14: simplified pollen diagram and squared chord distance values for the late-glacial period and the early Holocene. The lithology is modified after Troels-Smith (1955) and the pollen zones refer to Firbas (1949, 1954). LST: Laacher See Tephra. Nos. 1-6 mark peaks of the squared chord distance (for more details see text)

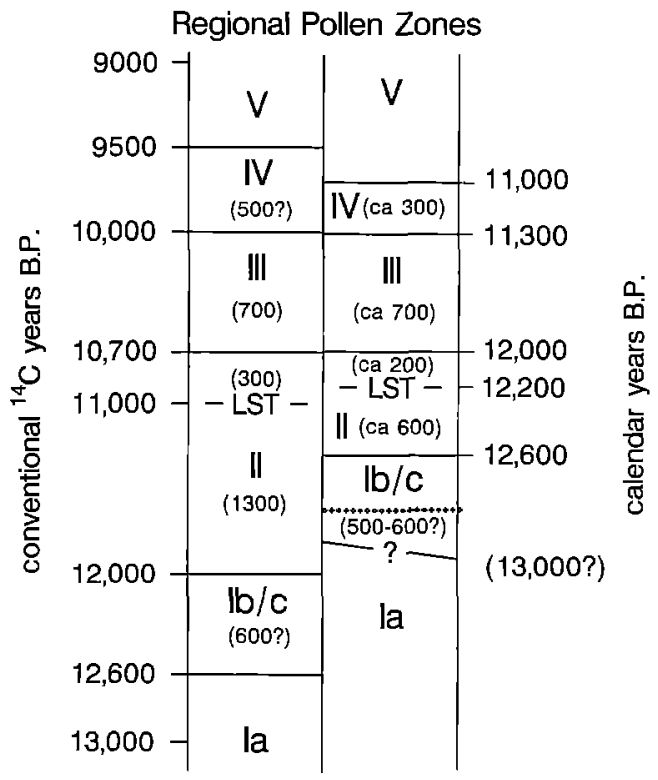

Fig. 4. Preliminary comparison of the duration of the regional pollen zones (Firbas 1949, 1954) for the Swiss Plateau: radiocarbon years versus calendar years (Lotter 1991). LST: Laacher See Tephra. The transition III/IV is assumed to correspond to the Pleistocene/Holocene transition dated at ca. 11300 cal. y BP (Becker and Kromer 1986) versus $1300{ }^{14} \mathrm{C} \mathrm{yr}$ ) and the Preboreal biozone (IV: ca. 300 varves versus $500{ }^{14} \mathrm{C} \mathrm{yr}$ ). If we correlate by matching the floating Soppensee varve chronology with the results of the dendrochronology at the onset of the Holocene (11280 calendar years BP, Becker and Kromer 1986; see Fig. 5 and Lotter 1991b), the varve chronology would extend as far back as ca. 13000 calendar years (cal. y) BP. The varve chronology would therefore be set off by ca. 1300 y towards older ages, and this discrepancy would steadily diminish with increasing age. This inconsistency between the sidereal and the radiocarbon time-scale has also been evidenced in other varve studies (e.g. Björck et al. 1988). In addition to the problems connected with the age plateaux it has further important implications for any meaningful calculation of rates of change during the late-glacial period.

\section{The rates of change}

Rates of palynological change, which are assumed to imply rates of past vegetational change, can be estimated by measuring the amount of palynological change per unit time between adjacent pollen samples. This is most conveniently done by computing dissimi- 


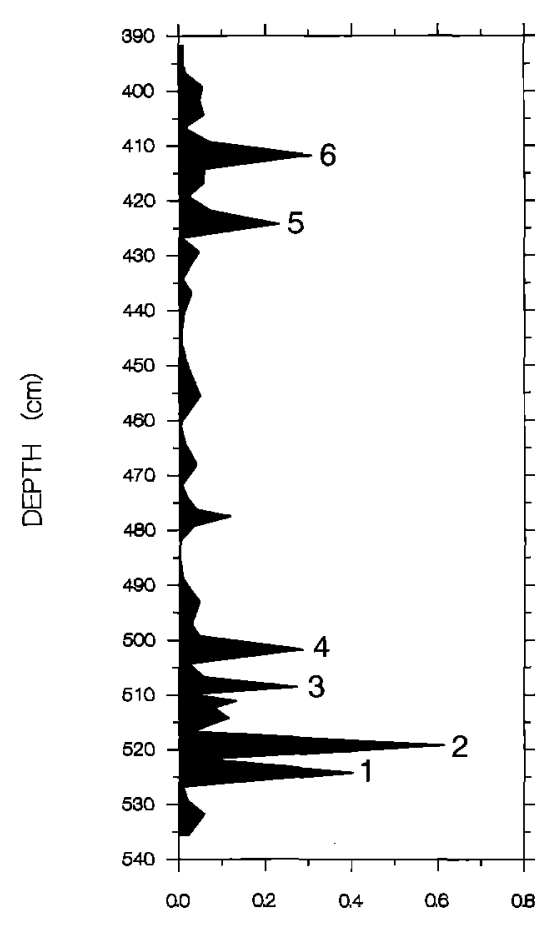

Squared Chord Distance (SCD)

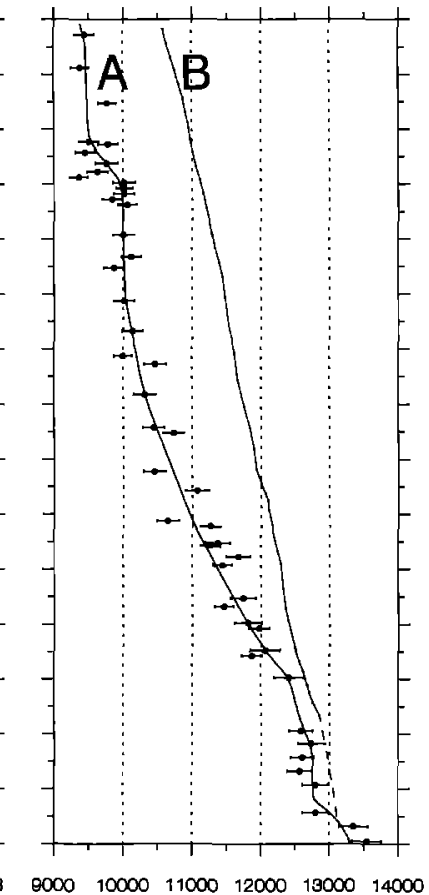

yrs B.P.

Fig. 5. Soppensee, core SO86-14: Dissimilarity coefficient, chronologies $\left({ }^{14} \mathrm{C}\right.$ from Rotsee in conventional radiocarbon years BP and varves from Soppensee in calendar years BP), and dissimilarity coefficients per unit time (note the scale differences). The radiocarbon chronology of Rotsee RL-300 (curve A, see also Fig. 2) has

larity coefficients and standardizing them to a uniform age unit (e.g. per 100 y, Jacobson and Grimm 1986; Jacobson et al. 1987). The squared chord distance (SCD) was used as a dissimilarity coefficient in this study because of its good signal-to-noise performance with pollen-percentage data (Prentice 1980; Overpeck et al. 1985).

For the present study 55 samples from the late-glacial pollen record of Soppensee with a pollen sum $(=100 \%)$ of between $500-1000$ pollen grains of upland vegetation were used. Spores and pollen of aquatics were excluded from this sum. Taxa with an abundance of less than $1 \%$ and an occurrence in less than 3 samples were excluded for the calculation of the SCD: this procedure left 20 taxa.

The SCD for the late-glacial pollen record from Soppensee shows six distinct peaks (Fig. 3). The first peak is caused by the increase in Juniperus, the second by the decrease of Juniperus and a simultaneous increase in Betula. The third peak marks the end of a regressive phase often attributed to the Older Dryas (Ic) biozone. Peak four reflects the spreading of Pinus and the associated decrease of Betula. Number five represents the onset of the Betula-phase in Preboreal. The last peak at the onset of the Boreal biozone (V) represents the transition from coniferous forest to deciduous forest.
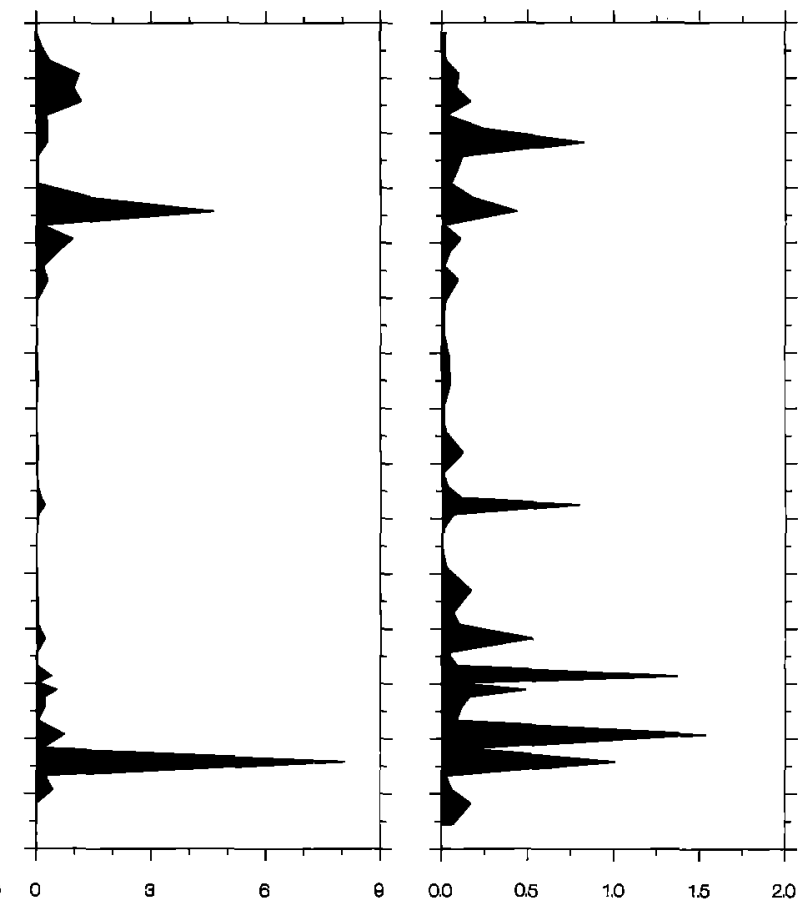

SCD/100 140 yrs

$\mathrm{SCD} / 100 \mathrm{cal} . \mathrm{yrs}$

been matched to the SO86-14 depth scale by correlation of the biostratigraphy, whereas the varve chronology (curve $B$ ) has been assessed on SO86-14 (dashed part of varve chronology is inferred by extrapolation). Nos. 1-6 mark peaks of the SCD

In contrast to Jacobson and Grimm (1986) and Jacobson et al. (1987), the rates of palynological change were not estimated from smoothed and interpolated evenly time-spaced pollen diagrams. The amount of time between adjacent samples was estimated by interpolation from the radiocarbon chronology (curve $A$ in Fig. 5) or by varve counts (curve B in Fig. 5). Each SCD value was then standardized on a uniform age basis of 100 years, both for cal. $y$ and ${ }^{14} \mathrm{C} y$.

If plotted against depth the six peaks are located at the same stratigraphical position (Fig. 5). Owing to the different calculation bases the amplitude differences for the peaks are almost an order of magnitude between the $\mathrm{SCD} / 100{ }^{14} \mathrm{C} y$ and the corresponding values per calendar years during the plateau phases. If we plot the SCD per unit time against time (Fig. 6) the two records can only be compared on the basis of the biozones, due to the inconsistencies between the two time-scales. Using the ${ }^{14} \mathrm{C}$ time-scale the highest values and the highest concentration of data-points are, of course, encountered around the plateaux (i.e. 12700, 10000, and 9500 y BP) due to bias in the ${ }^{14} \mathrm{C}$ chronology, whereas the values are evenly spread on the calendar time-scale. Despite differences in magnitude, the SCD/100 y peaks that are situated in a plateau of constant ${ }^{14} \mathrm{C}$ age (SCD 


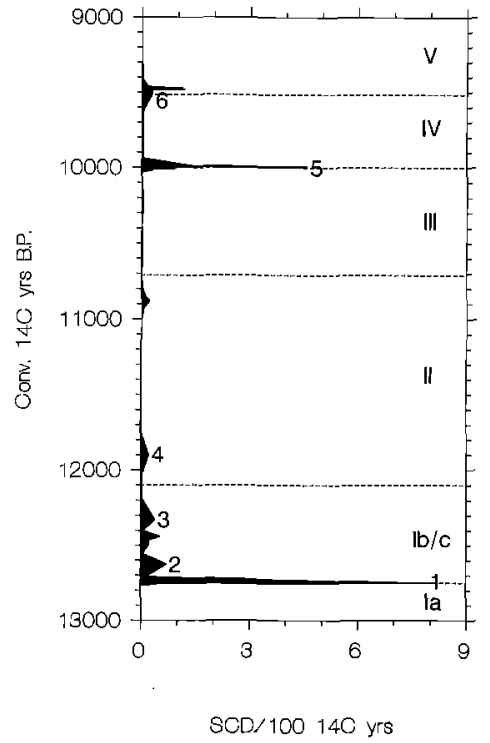

peaks 1,5 , and the peak after No. 6) are more pronounced if calculated on the basis of the radiocarbon chronology. The most important changes in the past vegetation, namely peaks 2 (reforestation) and 6 (transition from coniferous to deciduous forest), which are in fact already apparent in the pollen diagram, are suppressed if the rates of change are estimated on the basis of the available radiocarbon chronology, whereas they are well represented if estimated using the varve chronology. If the rates were estimated using a coarser age unit (e.g. 1000 years, Huntley 1990), the actual patterns of interest would be lost.

\section{Conclusions}

1. The presence of three phases of constant radiocarbon age during the late-glacial and early Holocene period prevents reliable estimation of any rates (e.g. rates of change, accumulation rates etc.) around 12700 , 10000 , and 9500 y BP on the basis of ${ }^{14} \mathrm{C}$ dates only. For spatial correlations these age plateaux could lead to a false synchroneity.

2. A discrepancy of changing magnitude between the radiocarbon time-scale and the sidereal time-scale (i.e. more calendar years than radiocarbon years) occurs during the late-glacial and early Holocene. Although an extension of the radiocarbon calibration curve into the late-glacial period is needed, it will not solve the problems connected with the ${ }^{14} \mathrm{C}$ plateaux. Moreover, interpolation of radiocarbon ages using only dates before and after such a plateau would just ignore the existence of a very real problem.

3. Therefore, any reliable estimation of late-glacial or early-Holocene rates of change from proxy-data is critically dependent on a reliable chronology independent of radiocarbon-dating, such as dendrochronology or varve chronology. Without such a chronology, apparent periods of rapid change cannot be distinguished from changes in the atmospheric ${ }^{14} \mathrm{C} /{ }^{12} \mathrm{C}$ ratio, and potentially erroneous and misleading conclusions about synchroneity of peaks of apparently rapid change may arise.

Acknowledgements. We should like to thank the following persons for their valuable help: M. Andrée, H. J. B. Birks, I. Hajdas, J. Hofmann, S. Juggins, M. Kummer, H. E. Wright Jr., and $H$. Zbinden. This study was supported by Swiss National Science Foundation (Project Nr 21-26567.89).

\section{References}

Ammann B (1989a) Late-Quaternary palynology at Lobsigensee. Regional vegetation history and local lake development. Diss Bot 137:1-157

Ammann B (1989b) Periods of rapid environmental change around 12500 and 10000 years BP, as recorded in Swiss lake deposits. J Paleolimnol 1:269-277

Ammann B, Lotter AF (1989) Late-Glacial radiocarbon- and palynostratigraphy on the Swiss Plateau. Boreas 18:109-126

Andrée M, Oeschger H, Siegenthaler U, Riesen T, Moell M, Ammann B, Tobolski $\mathrm{K}(1986){ }^{14} \mathrm{C}$ dating of plant macrofossils in lake sediment. Radiocarbon 28/2:411-416

Becker B, Kromer B (1986) Extension of the Holocene dendrochronology by Preboreal pine series, 8800 to $10000 \mathrm{BP}$. Radiocarbon 28/2B:961-967

Becker B, Kromer B (1990) Dendrochronology and radiocarbon calibration of the early Holocene. In: Barton N, Roe D \& Roberts A (eds) The late glacial of NW Europe. Oxford (in press)

Björck S, Berglund BE, Digerfeldt G (1988) New aspects of the deglaciation chronology of South Sweden. Geogr Polonica $55: 47-49$

Elias SA, Wilkinson B (1983) Lateglacial insect fossil assemblages from Lobsigensee (Swiss Plateau). Rev Paléobiol 2:189-204

Elias SA, Wilkinson B (1985) Fossil assemblages of Coleoptera and Trichoptera at Lobsigensee. In: Lang G (ed) Swiss lake 
and mire environments during the last 15000 years. Diss Bot 87:157-182

Firbas F (1949) Spät- und nacheiszeitliche Waldgeschichte Mitteleuropas nördlich der Alpen. Fischer, Jena. 480 pp

Firbas F (1954) Die Synchronisierung der mitteleuropäischen Pollendiagramme. Danm Geol Unders II/80:12-21

Hofmann W (1983) Stratigraphy of subfossil Chironomidae and Ceratopogonidae (Insecta: Diptera) in lateglacial littoral sediments from Lobsigensee (Swiss Plateau). Rev Paléobiol 2:205209

Hofmann W (1985a) Developmental history of Lobsigensee: subfossil Cladocera (Crustacea). In: Lang G (ed) Swiss lake and mire environments during the last 15000 years. Diss Bot 87:150-153

Hofmann W (1985b) Developmental history of Lobsigensee: subfossil Chironomidae (Diptera). In: Lang G (ed) Swiss lake and mire environments during the last 15000 years. Diss Bot $87: 154-156$

Huntley B (1990) Dissimilarity mapping between fossil and contemporary pollen spectra in Europe for the past 13000 years. Quat Res 33:360-376

Jacobson GL, Grimm EC (1986) A numerical analysis of Holocene forest and prairie vegetation in central Minnesota. Ecology 67:958-966

Jacobson GL, Webb T, Grimm EC (1987) Patterns and rates of vegetation change during the deglaciation of eastern North America. In: Ruddiman WF and Wright HE (eds) North America and adjacent oceans during the last deglaciation. The Geology of North America Vol K-3. Geological Society of America. Boulder Colorado. 277-288

Küttel M (1979) Pollenanalytische Untersuchungen zur Vegetationsgeschichte und zum Gletscherrückzug in den westlichen Schweizer Alpen. Berichte Schweizerische Botanische Gesellschaft 89:9-62

Lang G, Tobolski K (1985) Hobschensee - late-glacial and Holocene environment of a lake near the timberline. In: Lang $G$ (ed) Swiss lake and mire environments during the last 15000 years. Diss Bot 87:209-228

Lotter A (1988) Paläoökologische und paläolimnologische Studie des Rotsees bei Luzern. Pollen-, grossrest-, diatomeen- und sedimentanalytische Untersuchungen. Diss Bot 124:1-187

Lotter AF (1989) Evidence of annual layering in Holocene sediments of Soppensee, Switzerland. Aq Sci 51:19-30

Lotter AF (1991a) How long was the Younger Dryas? Preliminary evidence from annually laminated sediments of Soppensee (Switzerland). Hydrobiol 214:53-57

Lotter AF (1991b) Absolute dating of the late-glacial period in Switzerland using annually laminated sediments. Quat Res 35:321-330

Lotter AF, Zbinden H (1989) Late-Glacial palynology, oxygen isotope record, and radiocarbon stratigraphy from Rotsee (Lucerne), central Swiss Plateau. Eclogae geol Helv 82:191-202

Mangerud J, Andersen ST, Berglund BE, Donner J (1974) Quaternary stratigraphy of Norden, a proposal for terminology and classification. Boreas 3:109-128

Oberdorfer E (1937) Zur spät- und nacheiszeitlichen Vegetationsgeschichte des Oberelsasses und der Vogesen. Z Botanik 30:513-557

Overpeck JT, Webb T, Prentice IC (1985) Quantitative interpretation of fossil pollen spectra: dissimilarity coefficients and the method of modern analogs. Quat Res 23:87-108

Prentice IC (1980) Multidimensional scaling as a research tool in Quaternary palynology: a review of theory and methods. Rev Palaeobot Palynol 31:71-104

Stuiver M, Polach HA (1977) Reporting of ${ }^{14} \mathrm{C}$-data. Radiocarbon $19: 355-363$

Troels-Smith J (1955) Characterization of unconsolidated sediments. Danm Geol Unders IV, 3, 10:38-73

Welten M (1982) Vegetationsgeschichtliche Untersuchungen in den westlichen Schweizer Alpen: Bern-Wallis. Denkschr Schweiz Naturf Ges 95:1-104

Zbinden H, Andrée M, Oeschger H, Ammann B, Lotter A, Bonani G, Wölfli W (1989) Atmospheric radiocarbon at the end of the last glacial: an estimate based on AMS radiocarbon dates on terrestrial macrofossils from lake sediments. Radiocarbon 31:785-804

Zoller H (1987) Zur Geschichte der Vegetation im Spätglazial und Holozän der Schweiz. Mitt Naturf Ges Luzern 29:123-149 